each of Foundation, Registered, and Certified seed classes. Breeder seed of Secretariat is maintained by Grassland West Company. U.S. Plant Variety Protection of Secretariat has been applied for (no. 9700375).

$$
\begin{array}{r}
\text { P. Perdomo, T.J. Molnar, T.M. Ford, W.A. Meyer, } \\
\text { and C.R. FunK* }
\end{array}
$$

\section{Acknowledgments}

Sincere appreciation is expressed to Kevin N. Morris, Robert Shearman, and all other participants in the National Turfgrass Evaluation Program for their assistance in the evaluation of Secretariat. We also appreciate the assistance of Dirk A. Smith, Melissa Mohr, Ronald Bara, Barbara Smith, and Suichang Sun.

\section{References}

Ahmad, S., J.M. Johnson-Cicalese, W.K. Dickson, and C.R. Funk. 1986. Endophyte-enhanced resistance in perennial ryegrass to the bluegrass billbug, Sphenophorus parvulus. Entomol. Exp. Appl. 41:3-10.

Alderson, J., and W.C. Sharp. (ed.) 1994. Grass varieties in the United States. USDA-SCS Agricultural Handbook No. 170 (Revised). U.S. Gov. Print. Office, Washington, DC.
Fletcher, L.R. 1982. Observations of ryegrass staggers in weaned lambs grazing different ryegrass pastures. N.Z. J. Exp. Agric. 10:203-207.

Funk, C.R., P.M. Halisky, S. Ahmad, and R.H. Hurley. 1985. How endophytes modify turfgrass performance and response to insect pests in turfgrass breeding and evaluation trials. p. 127-145. In F. Lemaire (ed.) Proc. 5th Int. Turfgrass Res. Conf., Avignon, France. 1-5 July 1985. INRA Publ., Versailles, France.

Funk, C.R., P.M. Halisky, M.C. Johnson, M.R. Siegel, A.V. Stewart, S. Ahmad, R.H. Hurley and I.C. Harvey. 1983. An endophytic fungus and resistance to sod webworms: Association in Lolium perenne L. Bio/Technology 1:189-191.

Morris, K.N., and R. Shearman. 1999. National Perennial Ryegrass Test-1994. Final Report 1995-1998. NTEP no. 99-11. National Turfgrass Evaluation Program. USDA-ARS, Beltsville, MD.

P. Perdomo, Rutgers Cooperative Extension of Morris County, P.O Box 900-Courthouse, Morristown, NJ 07963-0900; T.M. Ford, Lebanon-Seaboard Corporation, P.O. Box 10, Huntsville, UT 84317; T.J. Molnar, W.A. Meyer and C.R. Funk, Plant Biology and Pathology Dep., 59 Dudley Rd., New Jersey Agric. Exp. Stn. (NJAES), Cook College, Rutgers Univ., New Brunswick, NJ 08901. Publication no. D-12155-12-02. Some of this work was conducted as part of NJAES Project no. 12155, supported by NJAES funds, other grants, and gifts. Additional support was received from the U.S. Golf Association- Golf Course Superintendents Association of America Research Fund, and the New Jersey Turfgrass Association. Registration by CSSA. Accepted 31 July 2002.*Corresponding author (basmith@aesop.rutgers.edu).

Published in Crop Sci. 43:439-440 (2003).

\title{
REGISTRATIONS OF GERMPLASMS
}

\section{Registration of Rust and Late Leaf Spot Resistant Peanut Germplasm Lines}

Four peanut (Arachis hypogaea L.) germplasm lines, ICGV 99001 (Reg. no. GP-118, PI 631072), ICGV 99003 (Reg. no. GP-119, PI 631073), ICGV 99004 (Reg. no. GP-120, PI 631074), and ICGV 99005 (Reg. no. GP-121, PI 631075), were released in 2001 by the Plant Materials Identification Committee of International Crops Research Institute for the Semi-Arid Tropics (ICRISAT), Patancheru, AP, India, for their resistance to foliar fungal diseases. These lines were derived from $A$. hypogaea and wild Arachis species crosses. ICGV\#99001 and 99004 belong to subsp. fastigiata var. vulgaris while ICGV\#99003 and 99005 belong to subsp. hypogaea var. hypogaea. ICGV\# 99001 and 99004 possess resistance to late leaf spot (LLS) [(caused by Phaeoisariopsis personata (Berk. \& Curt.) v. Arx = Cercosporidium personatum (Berk. \& Curt.) Deighton], and ICGV\# 99003 and 99005 have resistance to rust (caused by Puccinia arachidis Speg.).

The pedigrees of these germplasm are $A$. hypogaea $\times A$. villosa for ICGV 99001; $A$. hypogaea $\times[A$. duranensis $\times A$. stenosperma $]$ for ICGV 99003; A. hypogaea $\times A$. cardenasii for ICGV 99004; and A. hypogaea $\times[A$. batizocoi $\times A$. duranensis] for ICGV 99005. These wild Arachis species are immune or highly resistant to rust and/or LLS (Subrahmanyam et al., 1983; 1985). Cytologically stable tetraploid interspecific progenies were produced following triploid-hexaploid route of crossing in case of $A$. villosa and $A$. cardenasii, and amphidiploid route in case of $A$. batizocoi, $A$. duranensis, and $A$. stenosperma followed by intermitant backcrossing with recurrent A. hypogaea parent. These populations were evaluated under field conditions for rust and LLS following infector row screening technique (Subrahmanyam et al., 1995)

ICGV 99001 has decumbent two growth habit, sequential branching pattern, and medium-sized elliptic green leaves (IBPGR and ICRISAT, 1992). Its plant height averages $17 \mathrm{~cm}$ with a canopy breadth of $41 \mathrm{~cm}$. It has six primary branches and one secondary branch. It has $1-2-3$ seeded pods with no pod beak or pod ridges, slight pod reticulation, and slight to medium pod constriction. The seeds are round in shape. It has $720 \mathrm{mg} \mathrm{g}^{-1}$ meat content and a 100 -seed weight of $44 \mathrm{~g}$. The seeds contain $521 \mathrm{mg} \mathrm{g}^{-1}$ oil and $253 \mathrm{mg} \mathrm{g}^{-1}$ protein of dry seeds.

ICGV 99003 has decumbent three growth habit, alternate branching pattern, and small elliptic dark green leaves. Its plant height averages $18 \mathrm{~cm}$ with a canopy breadth of $44 \mathrm{~cm}$. It has six primary branches and 17 secondary branches. It has 2-1-3 seeded pods with slight to moderate pod beak and pod constriction, and moderate pod reticulation and pod ridges. The seeds are elongated to round in shape. It has $740 \mathrm{mg} \mathrm{g}^{-1}$ meat content, and a 100-seed weight of $55 \mathrm{~g}$. The seeds contain $531 \mathrm{mg} \mathrm{g}^{-1}$ oil and $181 \mathrm{mg} \mathrm{g}^{-1}$ protein of dry seeds.

ICGV 99004 has decumbent three growth habit, sequential branching pattern, and medium-sized elliptic green leaves. Its plant height averages $21 \mathrm{~cm}$ with a canopy breadth of $36 \mathrm{~cm}$. It has 2-1 seeded pods with slight to moderate pod constriction. The pod beak, pod ridges, and pod reticulation are absent. The seeds are round in shape. It has $730 \mathrm{mg} \mathrm{g}^{-1}$ meat content and a 100 -seed weight of $36 \mathrm{~g}$. The seeds contain $496 \mathrm{mg} \mathrm{g}^{-1}$ oil and $250 \mathrm{mg} \mathrm{g}^{-1}$ protein of dry seeds.

ICGV 99005 has decumbent two growth habit, alternate branching pattern, and medium-sized elliptic green leaves. Its plant height averages $11 \mathrm{~cm}$ with a canopy breadth of $37 \mathrm{~cm}$. It has six primary branches and eight secondary branches. It has 2-1-3 seeded pods with slight to moderate pod beak, moderate pod constriction and pod ridges, and moderate to slight pod reticulation. The seeds are elongated in shape. It has $690 \mathrm{mg}$ $\mathrm{g}^{-1}$ meat content, and a 100 -seed weight of $66 \mathrm{~g}$. The seeds contain $517 \mathrm{mg} \mathrm{g}^{-1}$ oil and $252 \mathrm{mg} \mathrm{g}^{-1}$ protein of dry seeds.

The oil quality, as measured by oleic $(\mathrm{O}) /$ linoleic $(\mathrm{L})$ fatty acid ratios, of $\mathrm{ICGV} 99003(\mathrm{O} / \mathrm{L}$ ratio $=1.53)$ is relatively better than that of ICGV\# 99001, 99004, and 99005 (O/L ratio $=1.16$ to 1.21 ). The seeds of all the lines have dark red testa color. ICGV\# 99001 and 99004 mature in $145 \mathrm{~d}$ and ICGV\# 99003 and 99005 in 156 d during the postrainy season (October-November to April-May) at ICRISAT, Patancheru, India. 
By means of infector row technique, these four germplasm were screened for resistance to rust and LLS under field conditions for 2 rainy seasons (June-July to October-November) at ICRISAT. They were evaluated on a 1-to-9 scale, where $1=$ no disease and $9=81$ to $100 \%$ foliage damaged, $1 \mathrm{wk}$ before harvest. The average resistant disease score ranged from 3.0 to 4.0 for rust and 3.0 to 5.5 for LLS as compared with 9.0 on the susceptible control TMV 2. ICGV\# 99001 and 99004 for LLS and ICGV\# 99003 and 99005 for rust recorded the lowest score in both seasons. These lines were also evaluated for components of resistance to LLS and rust under greenhouse conditions. Resistance to LLS in ICGV\# 99001 and 99004 is due to longer incubation (9.5-10.0 d as compared with $8 \mathrm{~d}$ in TMV 2) and longer latent (16-26 d as compared with $13 \mathrm{~d}$ in TMV 2) periods, reduced number of lesions per leaflet (83-116 as compared with 244 in TMV 2 at $20 \mathrm{~d}$ after inoculation (DAI)), smaller lesion diameter $(2.5-2.8 \mathrm{~mm}$ as compared with $6.6 \mathrm{~mm}$ in TMV 2 at $35 \mathrm{DAI}$ ), reduced sporulation score (1.8-2.7 as compared with 8.0 in TMV 2 at 35 DAI), and lower leaf area damage $(6.4-7.4 \%$ as compared with $39.0 \%$ in TMV 2 at 20 DAI). Resistance to rust in ICGV\# 99003 and 99005 is due to longer incubation (10.7-13.0 d as compared with $7.0 \mathrm{~d}$ in TMV 2) and longer latent (14-25 d as compared with $9 \mathrm{~d}$ in TMV 2 when first pustule sporulated) periods, reduced number of pustules per leaflet (52-110 pustules as compared with 310 in TMV 2 at $50 \mathrm{DAI}$ ), smaller pustule diameter $(0.6 \mathrm{~mm}$ as compared to $1.0 \mathrm{~mm}$ in TMV 2 at $50 \mathrm{DAI})$, reduced sporulation score (1.7-1.9 as compared with 9.0 in TMV 2 at 50 DAI), and lower leaf area damage (1.4-3.0\% as compared with $59.5 \%$ in TMV 2 at $50 \mathrm{DAI})$.

The Genetic Resources and Enhancement Program, ICRISAT Center, Patancheru AP 502324, India, will maintain seeds of these elite germplasm. Limited quantities of seed without limitations on research uses will be made available upon request. The seeds of these germplasm are also deposited with U.S. National Seed Storage Laboratory, 1111 S. Manson, St. Fort Collins, CO 80521-4500.

A.K. Singh, S.L. Dwivedi, S. Pande, J.P. Moss, S.N. Nigam, * AND D.C. SASTRI

\section{References}

IBPGR and ICRISAT. 1992. Descriptors for groundnut. IBPGR, Rome, Italy, and ICRISAT, Patancheru, India.

Subrahmanyam, P., D. McDonald, F. Waliar, L.J. Reddy, S.N. Nigam, R.W. Gibbons, V.R. Rao, A.K. Singh, S. Pande, P.M. Reddy, and P.V.S. Rao. 1995. Screening methods and sources of resistance to rust and late leaf spot of groundnut. (In Eng. Summaries in En, Fr, Sp, and Pt.). Information Bulletin no. 47. Patancheru 502324,
Andhra Pradesh, India: International Crops Research Institute for the Semi-Arid Tropics.

Subrahmanyam, P., J.P. Moss, D. McDonald, P.V.S. Rao, and V.R. Rao. 1985. Resistance to leaf spot caused by Cercosporidium personatum in wild Arachis species. Plant Dis. 69:951-954.

Subrahmanyam, P., J.P. Moss, and V.R. Rao. 1983. Resistance to peanut rust in wild Arachis species. Plant Dis. 67:209-212.

A.K. Singh, National Bureau of Plant Genetic Resources, Pusa Campus, New Delhi 110012; S.L. Dwivedi, S. Pande, and S.N. Nigam, International Crops Research Institute for the Semi-Arid Tropics (ICRISAT), ICRISAT Patancheru PO, 502324, Andhra Pradesh, India; J.P. Moss, Elachan Bhana, Clachan Seil, Oban, PA 34 4TL, UK; and D.C. Sastri, House \# 24, Sri Venkateswara Colony, Lothu Kunta, Secunderabad, 500015, India. Registration by CSSA. Accepted 30 June 2002.*Corresponding author (s.nigam@cgiar.org).

Published in Crop Sci. 43:440-441 (2003).

\section{Registration of RN582 Sorghum Germplasm Line}

RN582 sorghum [Sorghum bicolor (L.) Moench] germplasm line (Reg. no. GP-591, PI 628277) was developed jointly by the USDA-ARS and the Agricultural Research Division, Institute of Agriculture and Natural Resources, University of Nebraska, and was released in September 2001.

$\mathrm{RN} 582$ is an $\mathrm{S}_{6}$ selection from the cross $\left(\mathrm{RTx} 430 \mathrm{~ms}_{3} m s_{3} \times\right.$ E 35-1) $\times$ E 35-1. RTx430 was developed and released by the Texas Agricultural Experiment Station (Miller, 1984) and was provided to this project containing the nuclear male sterility gene $m s_{3}$ by A.B. Maunder in 1988. E 35-1 is an Ethiopian land race with white seed, tan necrotic plant color, 2-dwarf in height, late maturing, and was obtained from A. SotomayorRios in 1979. RN582 has tan necrotic plant color ( $\left.p p_{-}\right)$, white pericarp (_yy), thin mesocarp $(Z Z)$, normal $(W x W x)$ white endosperm, no testa $\left(b_{1} b_{1} \_\right)$, and juicy culms $(d d)$. RN582 has demonstrated high heterotic potential for grain yield with $10 \%$ higher yields when crossed to AWheatland than the check hybrid AWheatland $\times$ RTx430 over the 3 -yr period 1998 to 2000 , and $20 \%$ higher yields when crossed to ATx631 than the white seed tan plant check hybrid ATx631 $\times$ RTx437 in 2001 (Table 1). RN582 is adapted to the northern portion of the U.S. grain sorghum producing region and will reach anthesis $5 \mathrm{~d}$ earlier than RTx430 in that environment. RN582 is a strong restorer of fertility in A1 cytoplasm. Fertility reaction in other cytoplasmic sterility systems is not known. Nuclear male sterility has not been observed in RN582. Performance data for RN582 and its hybrids collected in 1998, 1999, 2000, and 2001 at Ithaca, NE, are presented in Table 1.

RN582 is a source of tan necrotic plant color and white

Table 1. Descriptive data for RN582, AWheatland $\times$ RN582 and ATx631 $\times$ RN582 hybrids.

\begin{tabular}{|c|c|c|c|c|c|}
\hline & Days to anthesis $\dagger$ & Height & Seed set: & Test weight & Yield \\
\hline Inbreds§ & & cm & $\%$ & $\mathrm{~kg} \mathrm{hL}^{-1}$ & $\mathbf{k g ~ h a}^{-1}$ \\
\hline RN582 & 82 & 96 & 100 & 63 & 6020 \\
\hline RTx430 & 87 & 133 & 90 & 50 & 4076 \\
\hline BWheatland (BTx399) & 71 & 104 & 80 & 59 & 5581 \\
\hline LSD 0.05 & 3 & 13 & 21 & 21 & 1693 \\
\hline \multicolumn{6}{|l|}{ Hybrids 1998-2000I } \\
\hline AWheatland × RN582 & 76 & 165 & 99 & 77 & 10849 \\
\hline AWheatland $\times \mathbf{R T} \times 430$ & 74 & 139 & 84 & 76 & 9845 \\
\hline LSD 0.05 & 1 & 4 & 11 & 4 & 627 \\
\hline \multicolumn{6}{|c|}{ Hybrids 2001\# (tan plant white seed) } \\
\hline ATx631 $\times$ RN582 & 77 & 150 & 100 & 56 & 6707 \\
\hline ATx631 $\times$ RTx437 & 76 & 131 & 100 & 54 & 5576 \\
\hline LSD0.05 & 1 & 8 & - & 6 & 714 \\
\hline
\end{tabular}

$\dagger$ Days from planting to $\mathbf{5 0} \%$ anthesis.

$\$$ Percent self seed set under pollinating bag.

§ Data for inbreds are from a randomized complete block design experiment with $n=22$ and four replications at 1999 at Ithaca, NE.

II Data for hybrids are means pooled over 3 yr from randomized complete block design experiments with four replications at Ithaca, NE, in 1998 ( $n=$

44), $1999(n=44)$, and $2000(n=39)$.

\# Data for tan plant white seed hybrids are from a randomized complete block design experiment with four replications at Ithaca, NE, in $2001(n=30)$. 